\title{
CARESSER OF LIFE: WALT WHITMAN AND THE CIVIL WAR
}

\author{
JEROME LOVING
}

These Hospitals, so different from all others-these thousands, and tens and twenties of thousands of American young men, badly wounded ... open a new world somehow to me, giving closer insights, new things, exploring deeper mines than any yet.

-Walt Whitman to Nathaniel Bloom and

John F. S. Gray, March 19, 1863

TOWARD THE END OF 1862 Walt Whitman traveled to war-torn Virginia in search of his brother, George. The poet stepped off the train at Falmouth Station, near Fredericksburg, and climbed a hill overlooking the Rappahannock River and the previous week's battle site. One of the first scenes that grimly welcomed him, he told his mother on December 29 , "was a heap of feet, arms, legs, \&c. under a tree in front a hospital."1 After finding George at his encampment and spending the next day with him and his regimental comrades ("Capt. Sims, Lieut. Frank Butler, Orderly McReady ... all used me well"), he began to visit the wounded of the Army of the Potomac. In his notebook he wrote of seeing "the hard accommodations and experiences of campaign lifethe shelter tents - the improvised fireplaces in holes in the ground, with small subterranean passages and small mud chimneys, lengthened out by a barrel with both ends knocked out." Near the Lacy House, the major hospital receiving the worst cases (he recalled in 1875 in Memoranda During the War), several bodies lay covered only by a "brown woolen blanket. In the door-yard, towards the river, are fresh graves, mostly of officers, their names on pieces of barrel-staves or broken boards, stuck in the dirt." In the subsequent week, such sights wore even harder on the poet:

The results of the late battle are exhibited everywhere about here in thousands of cases, (hundreds die every day,) in the camp, brigade, and division hospitals. These are merely tents, and sometimes very poor ones, the wounded lying on the ground, lucky if their blankets are spread on layers of pine or hemlock twigs, or small leaves. . . The ground is frozen hard, and there is occasional snow. I go around from one case to another. I do

Editor's Note: This essay is from the first chapter of Jerome Loving's new critical biography of Whitman, Walt Whitman: The Song of Himself, to be published by University of California Press. 
not see that I do much good to these wounded and dying; but I cannot leave them. Once in a while some youngster holds on to me convulsively, and I do what I can for him.

One day Whitman followed a burial party down to the river under a flag of truce. He made friends not only among the Fifty-First and the wounded in the other Union regiments but also with Confederate soldiers who had been taken prisoner. One of the Fifty-First from Brooklyn, where Whitman had known him as a lad, was lying on the cold ground, "all bloody, just after the arm was taken off." Another was a nineteen-year-old captain from Mississippi, whom he found at the Lacy House shortly after the young officer's leg was amputated. He was subsequently transferred to Emory Hospital in Washington, where Whitman visited him frequently. "Poor boy," he told friends back in Brooklyn. "He has suffered a great deal, and still suffers - has eyes as bright as a hawk, but face pale- our affection is quite an affair, quite romanticsometimes when I lean over to say I am going, he puts his arm round my neck, draws my face down, \&c."2

Although Whitman was slow to engage emotionally in the war effort, these kinds of experiences made it impossible for him ever to retreat from it again. For the poet the Civil War became a marriage ceremony of sorts-between him and his country-and his poignant wartime poems in Drum-Taps (1865) a betrothal and a spiritual renewal. Earlier-in "Song of Myself"-Whitman had portrayed himself as a bachelor before the American democracy, "of Manhattan the son, / Turbulent, fleshy, sensual, eating, drinking and breeding." This prewar self was representative of the American people, in the best tradition of Ralph Waldo Emerson (where the artist descends into the minds of everyone when he thinks for himself), but it also represented the egotist that found "no sweeter fat than sticks to my own bones." With the war the self-styled "caresser of life" became more of a democrat and less of a "kosmos."

In 1861 the war began, as Southern state after state seceded. These actions and their blow to democracy no doubt suggested the idea of a private secession to the Poet of Democracy. The man who would come to be known as the "wound dresser" stayed away from the conflict for almost two years. He had written some poems about loneliness and the need for companions in "Out of the Cradle Endlessly Rocking" and the "Calamus" series, and this mood prevailed amid the hubbub of the war. Shortly after the firing on Fort Sumter, he wrote a few upbeat poems about the war-recruiting poems, it seemed, that may have inspired enlistments when they appeared in the newspapers. In fact, exactly a week after the firing on Fort Sumter, on April 12, 1861, George Washington Whitman-one of the poet's five brothers-enlisted as a hundred-days soldier in the Thirteenth Regiment of the New York State 
Militia. In September of that year he reenlisted, this time in the FiftyFirst Regiment of New York volunteers. Shortly afterward, on May 28, 1862, another brother, Andrew Jackson Whitman, became a threemonths' soldier in the Union cause that seemed to worsen by the battle. ${ }^{3}$

The first two years of the Civil War are among the most obscure in the record of Whitman's life, second only to large patches of the famous "foreground" Emerson suspected when he first read Leaves of Grass in 1855. Whitman fairly disappears from all biographies between May 24, 1860, when he took the new Shore Line Railroad back from Boston after seeing the third edition of Leaves of Grass through the press, to December 16, 1862, when the Whitman household at 122 Portland Street, near Myrtle Avenue in Brooklyn, got its first indication that brother George had been wounded at the Battle of Fredericksburg. ${ }^{4}$ At thirty-six, when Walt Whitman published the first Leaves of Grass, he had looked his age. Seven years later, at forty-three, he looked fiftythree. Yet those same liquid eyes look out from Matthew Brady's photograph of 1863 as they do from the frontispiece in the first edition, their stare penetrating, as if to say-as Whitman does in "Song of Myself"- "I see through the broadcloth and gingham whether or no." His $\mathrm{X}$-ray vision in poetry had gotten him in a lot of trouble in the interim, especially after the third edition and the "Children of Adam" poems, which bluntly describe the sexual magnetism between a man and a woman. A phrenological exam made in 1849 had declared this six-foot, two-hundred-pound, still somewhat firmly apportioned male to be "voluptuous." By 1860 he was fulfilling the prophecy - if perhaps only vicariously and in the poems.

Whitman's disappearance may have been part of a pattern, begun in 1848 after the initial failure of his Free-Soil newspaper, The Freeman, and repeated in 1855, when he spent the summer in the fishing and whaling village of Greenport, at the northeastern end of Long Island, after publishing his first book of poetry. ${ }^{5}$ With the third edition of Leaves of Grass, instead of getting out of town to watch the literary fireworks, he dropped out of sight - at least as far as his future biographers were concerned. The disappearance may have been as much personal as political. The poems of the 1860 edition- "Children of Adam," "Calamus," "Out of the Cradle Endlessly Rocking," "As I Ebb'd with the Ocean of Life" - suggest that the late 1850s were "the darkest years of his life." Even the celebrative "Starting from Paumanok," written earlier, seems to force its optimism, even in its final version:

Starting from fish-shape Paumanok where I was born,

Well-begotten, and rais'd by a perfect mother,

After roaming many lands, lover of populous pavements,

...

I strike up for a New World. 
"Take my leaves America," he said in the poem, and in the context of his controversial literary career after 1855, the phrase seems almost a supplication. Here he resembles his mentor Emerson. At the close of "The Poet" (published in 1844) - the very essay that inspired Whitman as a young journalist when he heard it delivered as a lecture in 1842 in New York City-Emerson exhorted the American poets to "doubt not ... but persist. . . . Stand there, balked and dumb, stuttering and stammering, hissed and hooted." Emerson himself may have felt "balked and dumb" by 1842 - recently stunned by the sudden death of his fiveyear-old son and soon to pen his essay "Experience," which tempered the optimism of his earlier work. Certainly, Whitman was "hissed and hooted" for the latest expansion of his poetic vision. In the Saturday Press, perhaps the forerunner of The New Yorker, Leaves of Grass received a thrashing review that advised its author to commit suicide. ${ }^{8}$ By June of 1861, when he returned to newspaper work with the "Brooklyniana" series, his third edition was already lost in the steadily increasing mayhem of the war. Unable to collect revenues from their southern clients, his publishers had gone bankrupt. Better to secede himself for a time.

"Brooklyniana," a series of twenty-five pieces in the Brooklyn Standard between June 1861 and November 1862, turned back the clock, looking journalistically at the history of Long Island. The island, which stretched out 120 miles from Brooklyn to Montauk, was once the home of the "royal tribe" of old Wyandanch. "This chief," Whitman had written in the Brooklyn Daily Eagle of September 20, 1847, "held a position not unlike our American president." Long Island had been originally the home of thirteen distinct Indian tribes, where "the Indian inhabitants ... numbered a million and a half." Realizing this figure might be an exaggeration, he nevertheless insisted that the "red race" had been very numerous, "as evidenced by many tokens." Taking up perhaps for the first time a theme that would become the title of his life-long book, Whitman quoted an "ancient Indian" who "declared to one of the earliest inhabitants of Easthampton, that within his recollection the natives were as many as the spears of grass."

In the series Whitman quickly established the original superiority of Brooklyn to Manhattan. Manhattan, he wrote in No. 1, had been selected by Dutch settlers mainly "as an outpost or place for a trading station, a store and fort-and not for residences." Because of its sand and rock foundation, the employees of the West Indian Company had settled instead "on the aboriginal island of Paumanock" (or Paumanake, as it sometimes appeared in old Indian deeds). ${ }^{10}$ Also spelled "Paumanack," the American Indian name for Long Island meant "fishshaped." In No. 13 of the series, Whitman half in jest suggested changing the island's name back to Paumanok, as it might "be a kind of poetic justice to the departed tribes of the great nation of Lenni-Lapape, 
or Delawares, of which stock the aborigines of this region were a part." By the Civil War, this Indian nation had largely disappeared from the island and, indeed, from most of the East as a result of the American Policy of Removal. In Brooklyn and King's County the native residents had been the Canarsees, who-Whitman correctly guessed-had been extinct since 1800. "Now that they have all forever departed," he told a readership then preoccupied with war, "it seems as if their shades deserve at least the poor recompense of the compliment connected in preserving the old name by which they themselves designated and knew this territory." 11

Although the poet is today identified as much with Manhattan and Broadway as he is with Brooklyn and Long Island, his loyalty in 1861 was to the east-to the whole of Long Island and "The State of PAUMANOK!" Yet as recently as 1857, in "Broadway, the Magnificent!" Whitman had sung of Manhattan with the brilliance he'd put into the first two editions of Leaves of Grass. "Broadway!" he exclaimed in Life Illustrated, an upscale literary magazine published by his phrenologist friends Fowler \& Wells, "that ever-flowing land-river, pouring down through the center of Manhattan Island!" The implicit comparison of New York's most famous avenue with the mighty Mississippi, which he celebrated in writings connected with his visit to New Orleans in 1848, was well won: the river that ran through the heart of America had exchanged its muddy banks for "granite blocks, -its side-banks of marble, iron, plate-glass, brick, and wood." In 1857 Whitman was still upbeat about his chances as a poet and about the nation with poetry in its veins that he celebrated. Manhattan, or "Mannahatta" as he called it, borrowing another Indian name, was the greatest city in the great nation, and Broadway was the city's most brilliant symbol, its delights perfect filler for the poet's long catalogues.

This land-river ran continually between its banks, "ebbing and flowing with American men, women, and with strangers. There they pass, a hundred thousand a day,--sometimes two hundred thousand." In pointing out the historic spots from the Battery upward, Whitman mentioned the "Negro Plot" of 1741 in which "eighty-three persons, mostly blacks, were either burnt at the stake, hanged, transported, or sold into slavery for a conspiracy to destroy the city." One of the stakes where blacks were burnt, he noted, was at the intersection of Wall Street: "You who come down town to business in the morning! you little think of the horrid spectacle that corner more than once exhibited! the iron pillarthe chains - the fagots of dry wood and straw - the African negro in the middle - the pile touched off - the yells and howls and agonized shrieksthe crowd around stolid and indifferent." 12 Whitman was writing after the bloody incidents in Kansas over the proposed extension of slavery in the new territories, and like his fellow New Yorker Herman Melville (in 
"Benito Cereno," published in 1856), he was warning of the coming national storm over the old question of slavery in the New World.

At the time when Whitman was writing the "Brooklyniana" series, he had returned to the tranquillity of Greenport. The last stop on the Long Island Railroad, the whaling village was the home of the poet's older sister, Mary Elizabeth, who, more than twenty years before, had at the age of eighteen married Ansel Van Nostrand. The couple's five children are the only source of the Whitman family's descendants today. Like many of the men in his wife's family, Van Nostrand was a shipyard worker; he was also an alcoholic, whose regular binges gave Walt another reason to visit his elder sister. Since 1855, when his father died at age sixty-five, Whitman had been the family "patriarch," although "trouble shooter" is perhaps a more accurate characterization. $\mathrm{He}$ also attended to the problems of his younger married sister, a hypochondriac caught up in a bad marriage to a New England landscape artist, as well as those of an older brother with mental deterioration, resulting from a shipboard accident, and a probable case of syphilis, another brother beset by alcoholism and tuberculosis, and a third mentally and physically handicapped.

Whitman made his latest visit to Greenport and vicinity, as he recalled in "Brooklyniana" Nos. 37-39, during the fall of 1861. While the poet fished off the town dock, a party of lively girls, "conveyed by a clerical looking personage, and one or two younger fellows," invited him to join them on a pleasure cruise out to Montauk Point. "It was a very pleasant and sensible party," he told his Brooklyn readers; "the girls were unaffected ... and the minister laughed and told stories and ate luncheons, just like a common man, which is quite remarkable for a country clergyman." The poet who had in the 1860 edition of Leaves of Grass confessed to the "need of comrades" here reveled in the company of young ladies. He enjoyed the group's merry stories and riddles as it sailed out of Greenport "at a stiff rate," passing Gardiner's Island ("the first English settlement ever made in the present limits of the state of New York") on its way to the Montauk peninsula and the reserved home of what relatively few American Indians still remained on the tip of Long Island.

"Montauk Point!" he exclaimed in No. 38. "How few Americans there are who have not heard of thee-although there are equally few who have seen thee with their bodily eyes, or trodden on thy greensward." Once ashore, the party "took a long ramble to and fro," declaiming what they remembered to be lines from Shakespeare's Richard III. Intoxicated with the wilds of Long Island's easternmost tip, they "pranced forth" and threw their hats in the air, "aimed stones at the shrieking sea-gulls, mocked the wind, and imitated the cries of various animals in a style that beat nature all out!" After cooking dinner aboard 
their moored sloop, they found that nightfall prevented their safe return and spent the night onboard, returning to Greenport the next morning. In recalling the trip, Whitman blessed his "lucky star," he said, "merely to sail-to bend over and look at the ripples as the prow divided the water-to lie on my back and to breathe and live in that sweet air and clear sunlight - to hear the musical chatter of the girls, as they pursued their own glee-was happiness enough for one day."

It may bother some to think that this poet of the people was enjoying himself while his country -including his own brothers - was engaged in a bloody civil war. The Montauk outing, in fact, was a solitary voyage of the imagination - a verbatim account for the most part of an essay published under the pen-name of "Paumanok," in $1849 .{ }^{13}$ Nevertheless, Whitman appears at this point almost untouched by the conflict. $\mathrm{He}$ had, of course, already written those recruiting poems- "First $\mathrm{O}$ Songs for a Prelude," "Eighteen Sixty-One," and "Beat! Beat! Drums!"-which he would collect in Drum-Taps. But they reflected the North's initial excitement about the war, which was expected to be over after one or two decisive Northern victories. By the time he wrote of "loafing" out at Greenport and Montauk, the national mood had changed to bewilderment and impatience, many protesting that President Lincoln was too rigid with the seceding states. It was becoming more likely that a long and deadly conflict lay ahead.

Even Lincoln's Preliminary Proclamation to the emancipation of African slaves, which gave the rebellious states until New Year's Day 1863 to return to the Union or lose their slaves, failed to deter the South from its course of action. Brother George, who had just survived the Battle of Antietam (September 17, 1862), wondered why "Uncle Abe has issued a proclamation declaring the slaves free in all the States that are in rebellion." At the same time, Southern or border states that had not rebelled could keep their slaves, as Lincoln, in the Emancipation Proclamation of January 1, 1863, was to free slaves in every place except where he had the actual authority to do so. "I don't know what effect it is going to have on the war," George told Walt, "but one thing is certain, he has got to lick the south before he can free the niggers, and unless he drives ahead and convinces the south, before the first of January, that we are bound to lick them, and it would be better for them to behave themselves and keep their slaves, than to get licked and lose them. I don't think the proclamation will do much good."14

George's disregard for the slavery question may reflect the "New York feeling" that had kept the Empire State politically "neutral" on the issue ever since the signing of the Declaration of Independence, but the North as a whole - as Lincoln's presidential ploy suggests - was more committed to the integrity of the nation than it was to the abolition of slavery. Even when the Emancipation Proclamation was signed, it did not include slaves in the loyal slave states-Tennessee and those parts 
of Virginia and Louisiana under Northern control. ${ }^{15}$ Whitman, himself a pronounced anti-slavery person (though "free-soil" rather than the more radical "abolitionist"), was at least ambivalent about the place of black Americans in a society of snow-white "divine average," and it would take something more direct and dramatic to take his attention away from long-ago Paumanok or present-day Manhattan. In addition to writing the "Brooklyniana" series, between March and May 1862 he also contributed seven pieces entitled "City Photographs" to the New York Leader. The "Brooklyniana" pieces were anonymous, and the poet continued to keep his identity quiet in "City Photographs" by using the pseudonym "Velsor Brush," joining the maiden surnames of his maternal and paternal grandmothers. ${ }^{16}$ The poet has been called a "hack writer" as a journalist, a label that is probably unfair when we compare his work to what was passing for journalism (and "hack" journalism) in the era of two-penny political presses. But "Brooklyniana"-with a few startling exceptions - tends to reinforce the label with its cribbing from local histories.

The same is true with "City Photographs." It is as if Whitman were somewhere else, back in the 1840s as editor of the New York Aurora or the Brooklyn Daily Eagle, as he mixed statistics about the Broadway Hospital and its administrators with observations of the humanity that thrived and faltered in spite of the status quo. His descriptions of the hospital, and of the Bowery in other articles as well, come alive when he talks directly about the people involved, and we can understand how readily Whitman took up his famous hospital work once he moved to Washington, D.C., in 1863. Seeing (and listing for his readers just as he had catalogued humanity in Leaves of Grass) every patient from the amputee to the sufferer of delirium tremens, "Velsor Brush" exclaimed in the editorial of March 15: "What a volume of meaning, what a tragic poem there is in every one of those sick wards! Yes, in every individual cot, with its little card-rack nailed at the head."17 The future "wound dresser" and "good gray nurse" was already ministering to the sick and wounded-among them relatively few soldiers and mainly stage drivers recuperating from broken collarbones, arms, or legs acquired in collisions on the cobblestoned and congested Broadway. These teamsters were the poet's first "soldiers" and his introduction to hospital work. In "Broadway, the Magnificent!" he had described the avenue as alive with omnibuses: "The drivers, on their boxes, sharply look out for passengers, interrogating all with crooked thumb." In the first Leaves he would write: "The heavy omnibus, the driver with his interrogating thumb, the clank of the shod horses on the granite floor."

"I have spent," he wrote in the Leader of April 12, "two or three Sunday afternoons, of late in going around among these sick soldiers, just to help cheer and change a little the monotony of their sickness and 
confinement." Although Whitman took an active part in assisting physicians in the war (his narrator in Drum-Taps assists in amputations), much of his talent as "nurse" probably lay in the area of psychology, in engaging the former farmboys and city laborers as "dear friends" instead of patients. In a mood that anticipated the positive "joy" of the intense comradeship of his Washington nursing experiences, he remembered, on the first anniversary of Fort Sumter, one Sunday evening in a veteran's ward of the Broadway. It was "one of the most agreeable evenings of my life amid such a group of seven convalescent young soldiers from a Maine regiment. We drew around together, on our chairs, in the dimly-lighted room, and after interchanging the few magnetic remarks that show people it is well for them to be together, they told me stories of country life and adventures, \&c., away up there in the Northeast."18

Whitman was still biding his time, now in the company of real rather than imaginary friends, but he was also edging closer to the war. Or the war was getting closer to him. From Newbern, North Carolina, George, recently promoted from the ranks to second lieutenant, reported on confiscated Confederate stationery that General Ambrose E. Burnside's Ninth Army had "given the Secesshers another thundering, thrashing, and have gained a splendid victory." 19 Andrew, too, was getting closer to the war. Plagued by a tubercular cough, which finally took his life in 1863, and by an emotionally unstable wife, who joined the ranks of Brooklyn's wartime streetwalkers after her husband's death, Andrew probably sought out military life because he could not get steady work at the Brooklyn shipyard. When Lincoln called for more troops after Stonewall Jackson's successful Shenandoah Valley Campaign, George's old state militia reappeared with a fresh lot of recruits, Andrew among them. Walt Whitman may have started to hear the drums and bugles that he reproduced in "Beat! Beat! Drums!" and "First O Songs for a Prelude." In the latter, the drums produce "a shock electric" that prompts the mechanic, the lawyer, the wagon driver, and the salesman to enlist ("Squads gather everywhere by common consent and arm").

But still the poet was slow to commit himself. Near the end of Whitman's life, Thomas Wentworth Higginson, himself a wounded veteran, accused the poet of purposely avoiding military service in the war. ${ }^{20}$ At forty-three, however, Whitman was already too old for the rigors of combat and campside living (he recalled after the war that his brother George had traveled over 20,000 miles, marched across fifteen states, and "taken a hand in nearly all the historic campaigns of the war"). And even though he is alleged to have thrown a pro-slavery Democrat down the stairs of the Brooklyn Eagle office in the 1840s, Whitman was probably not inclined to combat, although in a wartime publication he hinted otherwise ${ }^{21}$ If Whitman was to participate in the war, he needed to find another role. 
The poet's lack of focus on wartime matters also reflected the North's confusion during the first eighteen months of the war. In spite of major battles at Bull Run, the North Carolina peninsula, Cedar Mountain, and Antietam, nothing was getting settled. In this respect, the Union experience resembled the American one in Vietnam little more than a century later, where villages captured or hills successfully defended at the cost of many lives lost their relevance as quickly as the newspaper headlines that publicized them. In both cases, it was the superior force that had to invade the enemy's territory. At the outset of the American civil war (as throughout the Vietnam conflict), the morale of that enemy was higher because it believed it was fighting a war for independence. In addition, Whitman's inattention may have reflected a widespread support for Confederate sentiment - as George's comment about the impending Emancipation Proclamation documents-which was strong in the state and city of New York as well as in the North generally. ${ }^{22}$ Whitman was more pro-Union than he was anti-slavery and favored with Lincoln the recolonization of Africans-though for Whitman the "colony" could have been located in the United States. Whitman began to shift his thoughts from Montauk and Broadway to Washington and Richmond only after repeated losses by Union troops made it clear that the war would be long and indeed even suggested that the Union might well be cut in two.

Closer to home and the more immediate reason for Whitman's interest in the war was a report in the New York Herald of December 16, 1862, that a "First Lieutenant G. W. Whitmore" was among the nearly 13,000 Federal troops either killed or wounded under the misguided efforts of Burnside, Lincoln's latest supreme commander, to engage Confederate forces at Fredericksburg, Virginia. George, meticulously considerate throughout the war of his family's fears back in Brooklyn, had been careful not to report himself among the wounded, but when his regimental commander, Colonel Robert B. Potter, noticed the "scratch" on George's cheek, he added Whitman's name to the list. From George's letters the family knew the names of all the officers in the Fifty-First and guessed correctly that "Whitmore" was a misprint for "Whitman," confirmed the next day in the New York Times ("Lieut. Whitman, Co. E, 51st New York-cheek"). To defuse the panicky state of his Brooklyn household, Walt left New York the same day, but not before securing letters of introduction from the former and current mayors of Brooklyn in the event he might have to relocate in order to nurse George in one of Washington's more than forty hospitals, where he expected to find him. ${ }^{23}$ Whitman went by ferry to New Jersey and by train to Philadelphia, where he had his pocket picked while changing trains for Washington. After arriving in the capital penniless and spending a day searching the hospitals for his wounded brother, he met Charles 
W. Eldridge, who had been one of the Boston publishers of the third edition of Leaves of Grass and was now employed in the army Paymaster's Office. He also found William Douglas O'Connor, another new government employee, in the Office of the Light House Board of the Treasury Department. O'Connor's anti-slavery novel Harrington had been published by the same Boston house in 1860. With Eldridge's and possibly O'Connor's help Whitman secured a military pass and went by barge down the Potomac River to Aquia Creek and then by train to Falmouth, arriving on December 19. There the Ninth army, under the command of Orlando B. Willcox following Burnside's promotion to commander of the Union forces, was encamped after the battle.

For all the Whitmans back on Portland Avenue knew, George was seriously wounded or even dead by this time. Living with the widowed Louisa Van Velsor Whitman were, along with Walt, his brother Jeff and his wife Martha Mitchell Whitman ("Mattie"), their young daughter Manahatta ("Hattie"), and the poet's disabled brother Edward ("Tobias"). Since Mrs. Whitman was also renting half the house to the family of John Brown, a tailor with two children, it is doubtful that other family members lived with her-though several must have been frequent visitors. ${ }^{24}$ From a camp near the Antietam battlefields in September, George had imagined the family back in Brooklyn: "ile bet now, that Mother is makeing pies. I think Mat is putting up shirt bosoms like the deuce so as to get through before dinner. I guess Sis [Hattie] is downstairs helping Mother mix the dough, Walt is upstairs writing, Jeff is down at the Office, Jess is pealing Potatoes for dinner, and Tobias has gone down cellar for a scuttle of coal. Bunkum I guess is around somewhere looking for a good chance to go sogering." Jesse Whitman, the poet's older brother, was sustained by temporary jobs at the Brooklyn shipyard not far from the Whitman residence, but his unstable and increasingly worsening mental condition, which culminated in a physical attack on family members, eventually forced Walt to have him committed to the Kings County Lunatic Asylum in 1864. ${ }^{25}$ "Bunkum" was the family nickname for Andrew Whitman, who had by then found his "chance to go sogering" and had returned home after three month's service. When news of George's probable wounding reached Brooklyn, Mattie threatened to go to Washington to nurse George herself. (She had before her the example of Louisa May Alcott, who had worked as a nurse in Washington in the winter of 1862-1863; she became ill, however, and returned home after only four months' service.) Mattie had taken the place of the two married Whitman daughters and was a constant comfort to the Whitman family, especially Walt and his mother. ${ }^{26}$ No doubt her excitable husband had insisted that somebody travel to Washington, or wherever they might find George. Mattie's threat that she might be the one (Jeff in those days often talked a bigger game than he carried out) probably convinced Walt to act at once. 
Needless to say, the entire Whitman family was frantic about George. Walt even sought out his Congressman, but Moses Fowler Odell could not see the poet on such short notice. By Friday afternoon, December 19, Whitman found George's regiment encamped outside Falmouth about a mile down river from the Lacy House, which had served as the headquarters of the Right Grand Division of Burnside's reorganized army until the battle and afterward as a hospital for Union wounded. ${ }^{27}$ $\mathrm{He}$ described the ordeal to his mother as "about three days of the greatest suffering I ever experienced in my life." "When I found dear brother George, and found that he was alive and well," he told her, "O you may imagine how trifling all my little cares and difficulties seemed-they vanished into nothing." 28

This was Walt Whitman's first visit to the front, and he could not have come upon more death and misery, the result of an ill-conceived and botched campaign. Historians agree that Burnside was foolish to go through with his planned attack on Fredericksburg (which constituted the straightest line to the Confederate capital in Richmond). Even his own generals, including Joseph Hooker, who would succeed Burnside as head of the Union troops in January, protested beforehand that the task was impossible unless the Union force outnumbered the Confederate armies two to one, which it did not. ${ }^{29}$ Arriving in Falmouth almost a month before the day of the main battle, Union troops under the command of Edwin V. Sumner (the Right Grand Division under which the Fifty-First New York Volunteers fought) could have taken Fredericksburg almost without a fight. But Burnside, under pressure to prevail where Lincoln's first top general, George B. McClellan, had delayed, delayed himself by ordering Sumner to wait for the delivery of pontoon bridges from Washington to ford the Rappahannock; thus, the Union crossing of the Rappahannock to occupy Fredericksburg was postponed until December 11, long after the combined forces of James Longstreet and Stonewall Jackson had reached the city to join with Robert E. Lee's forces behind a fortified stone wall atop Marye's Heights, just west of the city. Once the Union troops crossed the river under sharpshooters' fire and engaged the enemy in street fighting in Fredericksburg on December 13, they had to fight across a wide plain, exposing themselves to enemy artillery and percussion shells. As Union regiment after regiment attempted to cross, their ranks were scattered and thousands were killed and wounded, leaving the battlefield with bodies three-deep in some places.

As George told Jeff on January 8, 1863, as Burnside prepared to renew his ill-fated attack on Lee's fortifications with the notorious "Mud March" above Fredericksburg, "It was a mighty warm place we were into when I was hit as the Rebs had a battery planted right in front of us and not more than 1000 yards distance, and they poured grape and cannister into us like the very devil. . . . the range was so short, that they 
threw percussion shells into our ranks. . . . they would drop at our feet and explode killing and wounding three or four every pop. It was a piece of one of that kind of varmints that struck me in the jaw." The "spent slug" made a hole completely through George's cheek and rattled around in his mouth. ${ }^{30}$ As part of the Ninth Army, George's regiment-and its second brigade under General Edward Ferrero-made the final, suicidal assault late in the day on the Confederates, who enjoyed a superior position on the terraced slopes of Marye's Heights. In his official report, General Willcox recorded that George's brigade “encountered the full weight of the enemy's metal ... and marched under a heavy fire across the broken plain, pressed up to the field at the foot of the enemy's sloping crest, and maintained every inch of their ground with great obstinacy until after nightfall, but the position could not be carried." Although the architect of the Union assault was despondent over the legions of dead and wounded, Burnside insisted that he had come painfully close to succeeding and wanted (incredibly) to renew the attack the next day. ${ }^{31}$

Following the fighting on the afternoon and evening of the 13th, Burnside's army pulled back to Fredericksburg and then across the Rappahannock to Falmouth, unable in many cases to retrieve its wounded. One witness in George's division recalled, "That night was bitter cold and a fearful one for the front line hugging the hollows in the ground [to avoid enemy fire on the battle plain], and for the wounded who could not be reached. It was a night of dreadful suffering. Many died of wounds and exposure, and as fast as men died they stiffened in the wintry air, and on the front line were rolled forward for protection to the living. Frozen men were placed for dumb sentries." The FiftyFirst New York alone lost sixty-nine men in killed and wounded, including six of its officers. After hardly a year of combat, its number stood at 300 out of an original total of 1,000 soldiers. ${ }^{32}$ By the end of the war, George Whitman was the only member of his regiment who had started out with it back in the fall of 1861; the rest were either killed, wounded, sent home at the end of their three-year enlistments, or-in relatively few cases-transferred to other military units.

On December 28 Whitman accompanied a government transport of wounded (and dying) back to Washington, where he was met by O'Connor and his wife Nelly. The reunion was the beginning of a close friendship with the O'Connors, who were instrumental in Whitman's success in the Washington hospitals by providing the samaritan with a circle of friends sympathetic both to his current activity as "wound dresser" and to the controversial Leaves of Grass. To the very end of his life, the loyal O'Connor remembered the poet as he first arrived: "narrow at the flanks: the beard, the red in his face-not bloat . . . but a sort of sun-fish flush." ${ }^{33}$ It is not completely clear just when Whitman de- 
cided to remain in Washington, find a job, and continue the hospital work he had begun in New York City. "Since I have laid my eyes on dear brother George, and saw him alive and well-and since I have spent a week in camp ... and seen what well men and sick men, and mangled men endure-it seems to me," he told Mattie, "I can be satisfied and happy henceforth if I can get one meal a day." He added from the third-floor apartments rented by the O'Connors at 394 L Street, where he first lived in Washington, that he hoped soon to be back in Brooklyn with his family and "have some little steady paying occupation." This wish faded rapidly after seeing the broader results of the Fredericksburg massacre and in particular the wounded of the FiftyFirst in Campbell hospital: "O my dear sister, how your heart would ache to go through the rows of wounded young men, as I did-and stopt to speak a comforting word to them. There were 100 men in one long room, just a long shed neatly whitewashed inside. One young man was very much prostrated, and groaning with pain." This was John A. Holmes, about whom Whitman eventually wrote a touching report in the New York Times of February $26 .{ }^{34}$ There were so many "Brooklyn boys" in need of attention- "John Lowery, shot at Fredericksburg, and lost his left forearm, and Amos H. Vliet . . . has his feet frozen." These and others he had first seen at Falmouth, and their condition had worsened almost to a man.

By the middle of January, he decided to remain. From Brooklyn Jeff sent six dollars for the soldiers, and throughout the war he forwarded contributions collected from his friends and fellow engineers at the Brooklyn Water Works. ${ }^{35}$ Needing a job to sustain himself, Walt asked Emerson, who had been the first to recognize the genius of Leaves of Grass, for letters of introduction to William H. Seward, Secretary of State, and Salmon P. Chase, Secretary of the Treasury. Although Emerson had suddenly become mute after Whitman published his private letter of praise without permission in 1855, he broke his silence in 1863 by promptly sending the two letters of introduction. Apparently, neither thought it strange that a job-seeker might start so high in the bureaucracy to find what turned out to be a rather lowly position. In both letters, Emerson described Whitman "as a man of strong original genius, combining, with marked eccentricities, great powers $\&$ valuable traits of character." As it turned out, neither cabinet member helped Whitman. He never used his letter to Seward, and Chase, a presidential hopeful for 1864 who was bothered by the sexual aspects of Leaves of Grass, failed to assist - though he kept Emerson's letter as a souvenir. Senator Charles Sumner-whom Whitman saw on the matter three times-promised (albeit vaguely) to help. ${ }^{36}$ It was his former Boston publisher Charley Eldridge who came to the rescue by finding the poet his job as a copyist in the Army Paymaster's Office. 
Whitman's descriptions in letters, newspaper articles, and Specimen Days (based directly on journal entries written during the war) show that he was already becoming conscious of a new subject. Earlier he had thrown himself into the lifejoys of Brooklyn, Manhattan, New Orleans, and-by vicarious extension - the rest of the United States; now he immersed himself in the pathos of America's terrible quarrel with itself. At this point in the Drum-Taps poems, the tone shifts from the excitement of going to war to the recognition of the war's frightening toll on the American "camerado." Those wounded and dying young soldiers, of whom Whitman was to see more than 100,000 (by his count) during the next three years, stirred the poet's avuncular impulses, which had previously been reserved mainly for his own family members.

In Drum-Taps Whitman revived the old "Calamus" idea of male friendship, now lacing the poems with expressions of empathy instead of the earlier romantic longing that is today viewed as homoerotic. Because of the ongoing debate over the place of homosexuality in America today, the discussion of Whitman's sexual orientation will probably continue in spite of whatever evidence emerges. One fact is clear: he required from his earliest adult years the company of young men, working men, and "roughs." What may have changed with the war was the nature of that need. Just as the theme of the self in the early editions of Leaves of Grass gives way in Drum-Taps to the theme of altruism, where the self is celebrated in the selfless action of others and ultimately in the self of the assassinated Lincoln, the poet's desire for male friendship (or lovers) may have shifted to a desire for sons. The "Calamus" feeling was becoming sweetly solemnized (if never completely anesthetized) by death. ${ }^{37}$

The poignant Drum-Taps poems were born at Fredericksburg, where he had first seen "war-life, the real article." The scenes along the Rappahannock and subsequently in the military hospitals in Washington had opened up new horizons for him. "To these," he asked, "what are your dramas and poems, even the oldest and the tearfulest? Not old Greek mighty ones, where man contends with fate (and always yields) not Virgil showing Dante on and on among the agonized \& damned, approach what here I see and take a part in." What most impressed him so was the "American man-how he holds himself cool and unquestioned master above all pains and bodily mutilations." 38

Some of the greatest poems of Drum-Taps were conceived near the very battlefield they effectively describe. "Vigil Strange I Kept on the Field One Night," generally regarded as a vicarious military experience, reflects directly on the solemn Christmas Whitman spent at Fredericksburg: 
Vigil strange I kept on the field one night;

When you my son and my comrade dropt at my side that day,

One look I but gave which your dear eyes return'd with a look

I shall never forget,

One touch of your hand to mine O boy, reach'd up as you lay on the ground.

The next line has the poet speeding into battle, a surrogate experience for his hospital work in both Fredericksburg and later Washington. He returns to find his comrade and son-as he doubtless had with so many of his hospital charges- "in death so cold."

Also directly traceable to the Fredericksburg experience is "A Sight in Camp in the Daybreak Gray and Dim." Not only was the weather brutally cold that December, but the area around the river was thick with fog, delaying the building of the pontoon bridges used to cross over into Fredericksburg:

A sight in camp in the daybreak gray and dim,

As from my tent I emerge so early sleepless,

As slow I walk in the cool fresh air the path near by the hospital tent,

Three forms I see on stretchers lying, brought out there untended lying,

Over each the blanket spread, ample brownish woolen blanket,

Gray and heavy blanket, folding, covering all.

In "Down at the Front" (an essay penned in Falmouth on December 21), the same "brownish woolen blanket" is mentioned, and in another, "After First Fredericksburg" (December 23 to 31), the same wounded are lying on the ground outside the tent hospitals. ${ }^{39}$ Furthermore, two days before his departure for Washington, he walked in the early morning to find soldiers digging graves for the dead of George's regiment and another. "Death is nothing here," he recorded: "As you step out in the morning from your tent to wash your face you see before you on a stretcher a shapeless extended object, and over it is thrown a dark gray blanket-it is the corpse of some wounded or sick soldier of the reg't who died in the hospital tent during the night." 40

Similarly, the second stanza of "A Sight in Camp":

Curious I halt and silent stand,

Then with light fingers I from the face of the nearest the first just lift the blanket;

Who are you elderly man so gaunt and grim, with well-gray'd hair, and flesh all

sunken about the eyes?

Who are you my dear comrade?

Then to the second I step-and who are you my child and darling?

Who are you sweet boy with cheeks yet blooming?

In the third and final stanza, poetic transubstantiation takes place, creating a symbolic trinity of which the third soldier is a part: 
. . . a face nor child nor old, very calm, as of beautiful yellow-white ivory;

Young man I think I know you-I think this face is the face of the Christ himself,

Dead and divine and brother of all, and here he again lies.

We know that Whitman wrote the trial lines for the poem in his notebook while still at the place of inspiration: "Sight in daybreak (in camp in front of hospital tent) on a stretcher, three dead men lying, each with a blanket spread over him-I lift up one and look at the young man's face, calm and yellow. 'Tis strange! (Young man: I think this face of yours the face of my dead Christ)."41 Like most of Drum-Taps, this poem remained unchanged through all editions. ${ }^{42}$ These solemn poems were the poet's monument to immediate experience and as a result could never be revised. In one sense (emotionally, not politically) the war froze him in time. Even the earlier "Song of Myself," Whitman's greatest poem, underwent significant changes, but the Falmouth experience was personal, not poetic, history.

In 1855 Whitman had generally foresworn the poetic tradition of singing of wars and conquests. But in "To Thee Old Cause" (1871), which makes up part of the "Inscriptions" section of the definitive 1881 arrangement of Leaves of Grass (in a line that strikes readers as odd since the first three editions were written before the war), he announces, "my book and the war are one." In thanking Emerson for his letters of introduction, Whitman told him he intended "to write a little book about this phase of America, her masculine young manhood, its conduct under most trying of and highest of all exigency, which she, as by lifting a corner in a curtain, has vouchsafed me to see America, already brought to Hospital in her fair youth - brought and deposited here in this great, whited sepulchre of Washington itself." 43 This was to be Drum-Taps and later Memoranda During the War and finally a significant part of Specimen Days. Drum-Taps and the poems that follow it-such as "Proud Music of the Storm" and "Passage to India"-show us a poet as one of the folk. The poet of "Passage to India," for example, swiftly shrivels "at the thought of God," while the poet of "Song of Myself" is the son of God, or at least a close relative. This mystical claim in Whitman probably ceased with the 1855 edition. In the finest poem of the 1856 edition, "Crossing Brooklyn Ferry," the poet can master space and time but is no more (or less) eternal than those who will follow him a hundred years hence. By "Calamus" and the great seashore poems of the late 1850s, his mystical feeling about himself was gone, replaced by the "need of comrades." In the war he found "divinity" in the crucified sons of God instead of the resurrected self of "Song of Myself."

\section{Texas AEัM University}




\section{NOTES}

1 The Correspondence, ed. Edwin Haviland Miller (New York: New York University Press, 1961-1977), 1:59; hereafter abbreviated as C. See also "Our Wounded and Sick Soldiers," New York Times, December 11, 1864.

2 Prose Works 1892, ed. Floyd Stovall (New York: New York University Press, 19631964), 1:32-33, 43; hereafter abbreviated as $P W 1892$. $C, 1: 81$.

3 Civil War Letters of George Washington Whitman, ed. Jerome Loving (Durham: Duke University Press, 1975), 164-67; hereafter abbreviated as GWW. See Martin G. Murray, "Bunkum Did Go Sogering," Walt Whitman Quarterly Review 10 (Winter 1993), 142147. Another brother, Thomas Jefferson Whitman, paid $\$ 400$ for a military substitute in 1864. GWW, 14, 130 .

4 C, 1:54-60.

5 Richard Maurice Bucke, Walt Whitman (Philadelphia: David McKay, 1883), 26.

6 Elizabeth Robins Pennell, Charles Godfrey Leland: A Biography (Boston: Houghton Mifflin, 1906), 2:110-111.

7 The Complete Works of Ralph Waldo Emerson, ed. Edward Waldo Emerson (Boston: Houghton Mifflin, 1903-1904), 3:340. See also Jerome Loving, Emerson, Whitman, and the American Muse (Chapel Hill: University of North Carolina Press, 1982), 139-142.

8 Gay Wilson Allen, The Solitary Singer (New York: Macmillan, 1955), 260-262; see also $C, 1: 55$.

9 Uncollected Poetry and Prose of Walt Whitman, ed. Emory Holloway (New York: Doubleday, Doran, 1921), 1:180-181; hereafter abbreviated as UPP.

$10 U P P, 2: 224$.

11 UPP, 1:180; and UPP, 2:274-275.

12 Jerome Loving, “'Broadway, the Magnificent!': A Newly Discovered Whitman Essay," Walt Whitman Quarterly Review 12 (Spring 1995): 209-216.

13 UPP, 2:313-314; compare UPP, 2:317-320 with "Letters from a Travelling Bachelor," No. 9, in Joseph Jay Rubin, The Historic Whitman (University Park: Pennsylvania State University Press, 1973), 341-347.

$14 G W W, 71$.

15 Frank E. Vandiver, Blood Brothers: A Short History of the Civil War (College Station: Texas A\&M University Press, 1992), 14.

16 Walt Whitman and the Civil War, ed. Charles I. Glicksburg (Philadelphia: University of Pennsylvania Press, 1933), 17-18.

$17 G W W, 29$.

18 Glicksberg, 42.

$19 G W W, 45-50$.

20 Higginson wrote anonymous criticisms of Whitman and his hospital work in lieu of soldiering in Harper's Bazaar of March 5 and 26, 1887, and in the New York Evening Post of March 28, 1892, two days after the poet's death. See William Sloane Kennedy, 
The Fight of a Book for the World (West Yarmouth, Massachusetts, 1926), 70-71. In another attempt to tarnish Whitman's character, in 1897, Higginson was behind James Parton's threat to sue the Whitman estate for an allegedly unpaid loan made in 1857 (Horace L. and Anne Montgomerie Traubel Whitman Collection, Library of Congress).

21 Jerome Loving, “'Our Veterans Mustering Out'-Another Newspaper Article by Whitman about His Soldier-Brother," Yale University Library Gazette 49 (October 1974), 223.

22 J. G. Randall and David Herbert Donald, The Civil War and Reconstruction (Lexington, Mass.: D. C. Heath, 1969), 191, 223.

$23 G W W, 78$. Whitman's letters, obtained before he got Emerson's similar endorsement, were written by George Hall, "Late Mayor of Brooklyn," and by New York congressman Moses Fowler Odell; the first is undated; the second is dated December 16, 1862 (Horace L. and Anne Montgomerie Traubel Whitman Collection, Library of Congress).

24 Louisa Van Velsor Whitman to Walt Whitman, May 3, 1860 (Trent Collection, Duke University).

$25 G W W, 9-10$.

26 Letters of Martha Mitchell Whitman, ed. Randall H. Waldron (New York: New York University Press, 1977), 22.

27 U.S. Army War College Guide to the Battles of Chancellorsville and Fredericksburg, ed. Jay Luvaas and Harold W. Nelson (Carlisle, Pennsylvania: South Mountain Press, 1988), 3.

$28 C, 1: 58-59$.

29 Battles and Leaders of the Civil War (New York: Appleton, Century, Croft, 1956), $3: 129$.

30 GWW, 78-79; and Horace Traubel, With Walt Whitman in Camden (various publishers, 1906-1997), 8:44; hereafter abbreviated as WWC.

31 The War of the Rebellion: A Compilation of the Official Records of the Union and Confederate Armies (Washington: Government Printing Office, 1880-1901), 21:311$312,66$.

32 Major-General Darius N. Couch, "Sumner's 'Right Grand Division,"” in Battles and Leaders, 3:116-117; and Notebooks and Unpublished Prose Manuscripts, ed. Edward F. Grier (New York: New York University Press, 1984), 2:503; hereafter abbreviated as NUPM.

$33 W W C, 4: 260$.

34 NUPM, 2:502; and $C, 1: 62$.

35 Dear Brother Walt: The Letters of Thomas fefferson Whitman, ed. Dennis Berthold and Kenneth M. Price (Kent, Ohio: Kent State University Press, 1984), 22-24.

$36 C, 1: 61-68,73-74$. The source of the story about Chase's keeping the Emerson letter can be found in John Townsend Trowbridge, My Own Story: With Recollections of Noted Persons (New York: Houghton Mifflin, 1903), 388.

37 Emory Holloway, Whitman: An Interpretation in Narrative (New York: Alfred A. Knopf, 1926), 198. 
$38 C, 1: 81-82$.

39 PW 1892, 1:32-33.

40 NUPM, 2:508-509.

41 NUPM, 2:513.

42 Leaves of Grass, Comprehensive Reader's Edition, ed. Harold W. Blodgett and Sculley Bradley (New York: New York University Press, 1965), 306n.

$43 C, 1: 69$. 